\title{
COLLINS, John F. Revolt of the saints: memory and redemption in the twilight of Brazilian racial democracy. Durham: Duke University Press, 2015. 480 p.
}

Ion Fernández de las Heras*

* Universidade Federal de São Carlos - São Carlos, SP, Brasil

Pesquisador associado ao Grupo de Estudo e Pesquisa sobre Relações de Poder, Conflitos, Socialidades e ao Laboratório de Experimentações Etnográficas ionfdlheras@gmail.com 
Resulta algo insatisfatório, além de difícil, reduzir a uma simples resenha a complexidade de um livro como Revolt of the saints. Em primeiro lugar, chamar o texto de "etnografia" parece tão escasso quanto caracterizar como "trabalho de campo" as décadas de vida de Collins entre os habitantes do Centro Histórico de Salvador, na Bahia: primeiro como artesão (no final da década de 1980) e anos depois como antropólogo. O livro, nesse sentido, expressa um fragmento de vida, do próprio Collins e daqueles que transitaram o Pelourinho no decorrer de duas décadas de transformações urbanas, desde que, em 1985, a Unesco qualificou o bairro como Patrimônio da Humanidade e que, em 1992, começou a restauração do conjunto monumental. Em segundo lugar, se é de vidas particulares que estamos falando, resulta ainda mais deficiente condensar suas iminentes linhas de fuga (e sua potência na produção de significações) num argumento analítico que procure fazer as vezes de centro de convergência. Evitarei, desse modo, sintetizar aqui a multiforme narrativa de Collins numa tese antropológica unívoca.

Em todo caso, de que nos fala Collins? Podemos dizer que fala de um lugar e das vidas concretas que o compõem problematicamente. Vidas de residentes e de despejados, de moradores de rua, de prostitutas, músicos e malandros, de técnicos, "arquitetos de campo" (p. 226) e cientistas sociais da prefeitura, de políticos e de trabalhadores de ONGs; vidas como a do próprio antropólogo, que se compõem mutuamente e participam em seus trânsitos da gênese das socialidades. Collins fala também dos meios de captura que procuram fazer desse lugar (e das vidas que o compõem) uma forma estável e valorada segundo as prerrogativas do Estado-nação. Fala da patrimonialização não só de um sistema edificatório, mas da própria população que habita o bairro e o reclama, e dos aparelhos técnico-administrativos que confluem numa sistemática seleção de memórias. Fala de pertencimentos raciais como formas de propriedade, ou, dito de outro modo, da eficiência dos discursos que envolvem e produzem esse tópico, seja desde o ponto de vista das imposições do Estado (desde concepções paralelas à teoria da democracia racial) ou das heterogêneas contestações da própria população local. E fala da conflitiva gestão institucional de uma utopia (um não lugar), isto é, da transformação crítica de uma sociedade histórica real a partir da imaginação de uma sociedade-modelo constituída sob a mediação de um espaço-modelo que a integra necessariamente. Em palavras de Collins:

Hoje, próximo ao final da sua transformação num centro histórico dependente da aura e dos modos de viver de milhares de habitantes removidos desde 1992, 
este centro do período colonial, configurado simultaneamente como uma fonte de infecção e como um pedaço duradouro do passado da nação, brilha como um despovoado monumento ao que foi apresentado repetidamente no discurso oficial como a valiosa, e desconfortável, vitalidade do povo afro-brasileiro. [...] O projeto de restauração, baseado na suposta preservação fiel das memórias coletivas e da cultura popular, trabalha na prática como uma tentativa alienante e orientada para o futuro que procura redimir a população negra apresentando-a sob a necessidade de progresso civilizatório. (p. 3, tradução minha).

Trata-se, desse modo, de uma simultânea "sanitização" do espaço urbano e de uma "santificação" (p. 23) dos residentes que o reclamam e que, paradoxalmente, se veem condicionados a se deslocar a regiões urbanas afastadas à medida que o processo patrimonializador avança. Trata-se, enfim, da "moralização do solo" (p. 3) do Pelourinho e da Bahia e de sua constituição como objetos pensáveis (como "coisas em si", p. 348), isto é, da produção intelectual de um habitat (ou milieu) que faz as vezes de meio de identificação e transformação de si mesmo e de tudo o que o compõe e/ou transita.

Porém, é conveniente avisar que Collins não procura opor as prerrogativas $d a$ "comunidade" do Pelourinho a algo que poderíamos chamar de coerção e reificação do Estado. A sutileza do seu estudo consiste em etnografar a correspondência mútua de ambos (o que em última instância leva à sua dissolução) na gênese de um emaranhado concreto de compatibilizações e incompatibilizações, de modo que as atividades dos indivíduos que compõem essa população local sejam compreendidas em sua mediação (sua capacidade para produzir mundo), e não como o resultado de sua participação num agrupamento de caráter moral. Dito isso, pode-se adicionar que o autor está especialmente interessado na atualidade prática dos signos, isto é, na imanência da interação social como um constante processo de significação. Refiro-me, nesse sentido, aos signos "degenerados" (diria Peirce) e efêmeros que produzem graus heterogêneos de eficácia e associação e que, no caso do contexto do Pelourinho, atuam no seio de um complexo aparelho epistemológico cuja implementação procura a solidificação simbólica dos aspectos que contribuem para a versão oficial da história afro-baiana.

Pois bem, de que modo Collins nos fala de tudo isso? Em primeira pessoa, enquanto caminha pelas ruas, casas e ruínas do bairro e nos descreve com um detalhismo rigoroso os acontecimentos mais espontâneos, os enunciados mais rudimentares e as conversas mais informais, pois é no que elas envolvem e no 
seu particularismo que o autor encontra o modo de aceder ao fluxo problemático de pressuposições e interpretações através do qual as instituições e os cidadãos "entendem a produção de valor e a moldagem do consentimento no Brasil em volta das formas reificadas de cultura e de história" (p. 15, tradução minha).

O capítulo 1, desse modo, trata da inserção do próprio autor no panorama local, se posicionando entre as histórias de vida e morte de alguns dos residentes, e oferecendo "uma breve olhada nas artimanhas, nos contratempos, nas simulações e nas contradições que formam parte da vida do Pelourinho" (p. 40, tradução minha). No segundo capítulo, Collins apresenta um breve estudo arquivístico sobre a produção histórica do imaginário patrimonial baiano e nacional, recuperando enunciados esquecidos em cartas de personagens da Conquista ou de literatos modernistas. Nos capítulos 3, 4 e 5, retoma o plano etnográfico da interação local para descrever a relação entre determinados residentes do Pelourinho e diversos agentes do Estado (mais concretamente do Instituto de Patrimônio Artístico e Cultural da Bahia, Ipac) na mediação de aspectos como a sexualidade, a moral, o gênero, a identidade racial, a propriedade ou a posse (não unicamente das casas e do espaço urbano, mas do próprio corpo, do conhecimento ou da história). No capítulo 6, analisa uma simples interação, entre uma moradora de rua e uma equipe de saúde pública, com o intuito de desentranhar descritivamente a performativização de uma miríade de significações associadas aos aspectos tratados nos capítulos anteriores. Por último, no capítulo 7, a partir da descrição do curioso modo como os residentes locais se apropriam e traduzem ao português as letras de músicas jamaicanas de reggae, Collins discorre acerca da negociação das práticas e saberes que incidem na produção de pessoas, de memórias e do patrimônio cultural no Pelourinho.

Enfim, duas décadas de relações entre humanos, instituições, ideias e materiais estão condensadas descritivamente nesse livro. Se algo quis avocar aqui é a complexidade de uma narração etnográfica que escapa a qualquer resumo e que só pode ser efetivamente compreendida em sua leitura completa. 